\title{
Pengaruh Model Pembelajaran TTW Berbantuan Penilaian Portofolio Terhadap Sikap Disiplin dan Hasil Belajar IPS
}

\author{
${ }^{*}$ Ketut Juni Ariati ${ }^{1}$, Nyoman Dantes ${ }^{2}$, Desak Putu Parmiti ${ }^{3}$ \\ ${ }^{13}$ Pendidikan Guru Sekolah Dasar, Universitas Pendidikan Ganesha, Indonesia \\ ${ }^{2}$ Bimbingan Konseling ,Fakultas Ilmu Pendidikan, Universitas Pendidikan Ganesha, Indonesia
}

\author{
A R T I C L E I N F O \\ Article history: \\ Received 10 May 2019 \\ Received in revised form \\ 10 June 2019 \\ Accepted 15 July 2019 \\ Available online 29 August \\ 2019 \\ Kata Kunci: \\ penilaian portofolio, sikap \\ disiplin, TTW. \\ Keywords: \\ portfolio assessment, \\ discipline attitude, TTW
}

\begin{abstract}
A B S T R A K
Berdasarkan hasil observasi, ditemukan bahwa sikap disiplin dan hasil belajar IPS siswa masih rendah. Penelitian ini bertujuan untuk mengetahi pengaruh model pembelajaran Think Talk Write (TTW) berbantuan penilaian portofolio terhadap sikap disiplin dan hasil belajar IPS. Penelitian ini merupakan penelitian quasi experiment dengan desain nonequivalent post test only control group. Jumlah populasi dalam penelitian ini adalah 153 orang dan sampel penelitian berjumlah 68 orang yang diambil dengan teknik group desain random sampling. Data sikap disiplin dikumpulkan dengan menggunakan metode non tes berupa lembar kuesioner dan data hasil belajar IPS dikumpulkan menggunakan tes pilihan ganda. Data dianalisis dengan statistik inferensial (Manova). Hasil penelitian menunjukkan bahwa: 1) terdapat perbedaan sikap disiplin antara siswa yang mengikuti model pembelajaran Think Talk Write berbantuan penilaian portofolio dengan siswa yang mengikuti pembelajaran konvensional $\left(F_{\text {hitung }}=13,48>F_{\text {tabel }}\right.$ $=3,99)$; 2) terdapat perbedaan hasil belajar antara siswa yang
\end{abstract} mengikuti model pembelajaran (TTW) berbantuan penilaian portofolio dengan siswa yang mengikuti pembelajaran konvensional ( $\left.F_{\text {hitung }}=82,78>F_{\text {tabel }}=3,99\right)$ dan 3 ) secara simultan, terdapat perbedaan sikap disiplin dan hasil belajar IPS siswa yang mengikuti model pembelajaran (TTW) berbantuan penilaian portofolio dengan siswa yang mengikuti pembelajaran konvensional $(F=6,743 ; p<0,05$. Berdasarkan temuan tersebut, dapat disimpulkan bahwa model pembelajaran (TTW) berpengaruh positif terhadap sikap disiplin dan hasil belajar IPS siswa.

\section{A B S T R A C T}

This study aimed to determine the effect of the Think Talk Write (TTW) learning model assisted by portfolio assessment on discipline attitudes and social studies learning outcomes. This research was a quasi-experimental study with a nonequivalent post test only control group design. The population in this study was 153 sudents and the study sample numbered 68 students that taken by group random sampling technique. Disciplinary attitudes data were collected by non-test methods in the form of observation sheets and questionnaires and social studies learning outcomes data were collected using multiple choice tests. Data analyzed by descriptive statistics and Manova. The results showed that: 1) there were differences in disciplinary attitudes between students who participated in the Think Talk Write learning model assisted by portfolio assessment with students who followed conventional learning $(F=13.48>$ Ftable $=3.99)$; 2) there are differences in learning outcomes between students who follow the learning model (TTW) assisted by portfolio assessment with students who follow conventional learning ( $F$ count $=82.78>$ Ftable $=3.99)$ and 3 ) simultaneously, there are differences in disciplinary attitudes and learning outcomes of IPS students who follow the learning model (TTW) with students who take conventional learning $(F=6.743 ; p<0.05$. Based on these findings, it can be concluded that the learning model (TTW) has a positive effect on students' discipline and social studies learning outcomes. 



\section{Pendahuluan}

Menurut Undang-Undang Sistem Pendidikan Nasional No.20 Tahun 2003 pasal 1 butir 1, pendidikan adalah: "usaha sadar dan terencana untuk mewujudkan suasana belajar dan proses pembelajaran agar peserta didik secara aktif mengembangkan potensi dirinya untuk memiliki kekuatan spiritual keagamaan, pengendalian diri, kepribadian, kecerdasaan, akhlak mulia, serta keterampilan yang diperlukan dirinya, masyarakat, bangsa dan Negara." Pendidikan nasional bertujuan: "untuk mengembangkan potensi peserta didik agar menjadi manusia yang beriman dan bertakwa kepada Tuhan Yang Maha Esa, berakhlak mulia, cakap, kreatif, mandiri, dan menjadi waarga Negara yang demokratis serta bertanggung jawab" (UU Sisdiknas No. 20 tahun 2003 pasal 3) (Ayu, 2017).

Ilmu Pengetahuan Sosial (IPS) merupakan salah satu mata pelajaran yang diberikan kepada siswa sekolah dasar. (Trianto, 2010:171-172), "IPS merupakan integrasi dari berbagai ilmu-ilmu sosial seperti, sosiologi, sejarah, geografi, politik, hukum, dan budaya atas dasar realitas dan fenomena sosial yang terjadi di masyarakat". Melalui ilmu pengetahuan sosial siswa mampu mengamati, merasakan, berkomunikasi serta berinteraksi sebagai mahluk sosial dalam kehidupan sehari-hari. Selain itu Susanto 2013:138) berpendapat bahwa "Hakikat IPS adalah untuk mengembangkan konsep pemikiran yang berdasarkan realita kondisi sosial budaya yang ada dilingkungan siswa, sehingga dengan memberikan pendidikan IPS diharapkan dapat melahirkan warga negara yang baik dan bertanggung jawab terhadap bangsa dan negaranya".

Pelajaran IPS pada umumnya tidak dianggap oleh siswa sebagai pelajaran yang sukar. Para siswa tidak pernah mengategorikan sebagai mata pelajaran yang sukar seperti halnya pelajaran Matematika, Bahasa Inggris dan lain-lain. Tetapi pada kenyataannya nilai hasil belajar siswa pada mata pelajaran IPS tidak lebih baik dari mata pelajaran yang dianggap sukar bagi siswa. Permasalahan ini muncul bukan hanya karena kemampuan dan motivasi belajar siswa yang kurang, tetapi juga faktor lingkungan belajar yang kurang mendukung. Dalam hal ini kreativitas guru IPS dalam mengelola pembelajaran mempunyai pengaruh yang sangat besar dalam meningkatkan hasil belajar siswa. Selain itu bila dilihat dari materi IPS pada mata pelajaran IPS aktivitas pembelajaran banyak mengandung unsur menyimak dan mendengarkan.

Mengingat pentingnya mata pelajaran tersebut, maka dalam pembelajaran Ilmu Pengetahuan Sosial (IPS) harus diberikan secara 4 bermakna agar siswa dapat memahami sajian materi yang terkandung di dalamnya. Namun pada pelaksanaanya, seringkali mata pelajaran ini menjadi tidak bermakna dan terkesan sulit untuk dipelajari karena identik dengan hafalan materi yang banyak dan menjadi salah satu mata pelajaran yang kurang disenangi oleh siswa. Hal tersebut diketahui dari penelusuran dokumentasi hasil belajar dan pengamatan kegiatan pembelajaran yang dilakukan oleh peneliti pada tanggal 21 Desember 2018 di gugus IX Kecamatan Banjar. Berdasarkan hasil pengamatan di kelas dalam pelaksanaan pembelajaran IPS, terdapat beberapa permasalahan yang muncul yakni; (1) proses pembelajaran berpusat pada guru (teacher centered), (2) siswa kurang aktif dan percaya diri, serta kurang memanfaatkan kesempatan untuk bertanya pada guru, (3) siswa kurang tertarik dengan pelajaran IPS yang ditandai dengan banyak siswa yang tidak memperhatikan penjelasan guru, siswa enggan merangkum materi yang telah diberikan, (4) aktivitas yang melibatkan siswa masih kurang sehingga menyebabkan pembelajaran kurang bermakna, (5) guru belum menggunakan model pembelajaran Think Talk Write (TTW) pada pembelajaran IPS, (6) rendahnya hasil belajar IPS pada kelas III.

Namun dalam kenyataannya, proses pembelajaran IPS di SD gugus IX Kecamatan Banjar masih berorientasi pada pentransferan ilmu saja dari guru ke siswa dengan kegiatan yang didominasi oleh guru. Keterlibatan siswa dalam pembelajaran masih terbatas pada penerimaan materi yang disampaikan dengan metode ceramah. Dalam pembelajaran, siswa masih pasif menunggu informasi. Hal ini berdampak pada hasil belajar siswa. Dari data hasil UTS siswa kelas III pada semester I yang diperoleh, rata-rata hasil belajar IPS di SD gugus IX Kecamatan Banjar masih rendah, yang dapat dilihat pada Tabel 01. berikut ini. 
Tabel 1. Rata-rata nilai UTS IPS Kelas III

\begin{tabular}{|c|c|c|c|c|c|c|c|}
\hline \multirow[t]{2}{*}{ No } & \multirow[t]{2}{*}{ Nama Sekolah } & \multirow[t]{2}{*}{ Kelas } & \multirow[t]{2}{*}{$\begin{array}{l}\text { Jumkah } \\
\text { Siswa }\end{array}$} & \multirow[t]{2}{*}{$\begin{array}{l}\text { KKM } \\
\text { Sekolah }\end{array}$} & \multicolumn{2}{|c|}{$\begin{array}{l}\text { Jumlah Siswa ya } \\
\text { Mencapai KKM }\end{array}$} & \multirow{2}{*}{$\begin{array}{l}\text { Rata- } \\
\text { Rata } \\
\text { Nilai }\end{array}$} \\
\hline & & & & & Tuntas & Tidak Tuntas & \\
\hline 1. & SD Negeri 1 Gobleg & III & 12 & 70 & 2 & 10 & 58,75 \\
\hline 2. & SD Negeri 2 Gobleg & III & 37 & 70 & 9 & 28 & 62,18 \\
\hline 3. & SD Negeri 3 Gobleg & III & 7 & 65 & 2 & 5 & 57,14 \\
\hline 4. & SD Negeri 4 Gobleg & III & 31 & 63 & 10 & 21 & 58,45 \\
\hline 5. & SD Negeri 5 Gobleg & III & 26 & 67 & 8 & 18 & 61,11 \\
\hline 6. & SD Negeri 6 Gobleg & III & 15 & 70 & 2 & 13 & 59 \\
\hline 7. & SD Negeri 2 Pedawa & III & 25 & 65 & 8 & 17 & 59,56 \\
\hline & Jumlah & & 153 & - & 41 & 112 & - \\
\hline
\end{tabular}

Dalam tabel tersebut, tampak bahwa rata-rata nilai siswa kelas III masih di bawah KKM. Rendahnya rata-rata nilai IPS tersebut, menunjukkan bahwa hasil belajar siswa rendah. Berdasarkan hasil wawancara dengan guru kelas III di SD gugus IX Kecamatan Banjar diketahui bahwa hasil belajar IPS siswa pada aspek menulis, berbicara, dan menyimak masih rendah. Hal tersebut dikarenakan pembelajaran yang masih berpusat pada guru dan guru mengandalkan metode ceramah. Sehingga mata pelajaran IPS dianggap sebagai pelajaran yang membosankan. Hal ini mengakibatkan siswa menjadi jenuh dan bosan dalam mengikuti pembelajaran IPS di kelas, sehingga berdampak pada rendahnya hasil belajar IPS siswa kelas III SD di gugus IX Kecamatan Banjar. Untuk mengatasi permasalahan tersebut, diperlukan inovasi dari guru untuk mengemas pembelajaran IPS, agar pembelajaran IPS digemari oleh siswa. Saat mengikuti proses proses pembelajaran, inovasi yang kreatif sangat diperlukan agar siswa bisa mengikuti proses belajar dengan baik. Salah satu inovasi model pembelajaran yang dapat digunakan agar siswa dapat ikut terlibat aktif dalam proses pembelajaran sehingga berdampak pada peningkatan hasil belajar IPS siswa kelas III SD di gugus IX Kecamatan Banjar adalah menggunakan model Think Talk Write (TTW).

Model pembelajaran TTW ini merupakan suatu model pembelajaran yang melatih keterampilan siswa menulis dan menekankan perlunya siswa mengomunikasikan hasil pemikirannya (Juniardi, 2017). Alur kemajuan strategi (TTW) dimulai dari keterlibatan siswa dalam berfikir atau berdialog dengan dirinya sendiri setelah proses membaca (Hidayat, 2017). Berdasarkan pemaparan model pembelajaran TTW tersebut, maka diduga model pembelajaran TTW akan dapat mamacu siswa dalam belajar sehingga hasil belajar siswa akan menjadi maksimal. Model pembelajaran Think Talk Write (TTW) ini akan lebih berhasil dengan berbasis penilaian portofolio. Menurut Surapranata dkk, (2007:21), Penilaian portofolio merupakan penilaian berbasis kelas terhadap sekumpulan karya peserta didik yang tersusun secara sistematis dan terorganisasi yang diambil selama proses pembelajaran dalam kurun waktu tertentu, digunakan oleh guru dan peserta didik untuk memantau perkembangan pengetahuan, keterampilan, dan sikap peserta didik dalam mata pelajaran tertentu.

Dengan adanya portofolio mempermudah siswa dan guru serta orang tua mengetahui kekurangan yang dimiliki oleh siswa sehingga kedepannya dapat lebih dipahami (Suadnyana, 2016).

Hasil belajar siswa berupa kemampuan-kemampuan yang diperoleh dan dimiliki oleh siswa setelah melalui aktivitas belajar. Rusman, (2015:67) hasil belajar adalah "kemampuan yang dimiliki siswa setelah ia menerima pengalaman belajarnya”. Hasil belajar pada konteks ini lebih mengarah pada pembelajaran IPS sangat erat kaitannya dengan belajar atau proses belajar dan hasil belajar siswa.

Adapun model pembelajaran yang tepat untuk melibatkan siswa secara totalitas adalah model pembelajaran Think Talk Write (TTW) yang berbantuan portofolio terhadap sikap disiplin, karena dengan menerapkan model tersebut siswa akan lebih aktif selama proses pembelajaran. Menurut Anas Sudjono (dalam Nurul, 2016) sikap merupakan bagian dari tingkah laku manusia sebagai gejala atau gambaran kepribadian yang memancar kelur. Dan disiplin dalam belajar sangat diperlukan, karena disiplin pada hakikatnya akan tumbuh dan terpancar dari hasil kesadaran manusia. Sebaliknya, disiplin yang tidak bersumber dari kesadaran hati nurani akan menghasilkan disiplin yang lemah dan tidak akan bertahan lama. Selain menerapkan model pembelajaran Think Talk Write (TTW) di dalam pembelajaran IPS, guru juga harus melakukan penilaian, penilaian ini sangat penting dalam proses pembelajaran. Banyak guruguru yang menilai pengetahuan siswanya saja. Adapun penilaian yang akan digunakan yaitu penilaian portofolio. Portofolio dapat memperlihatkan perkembangan kemajuan belajar peserta didik melalui karyanya (Rahmawati, 2016). Dari penilaian tersebut guru dapat mengetahuan hasil belajar siswa yang lebih baik.

Kegiatan ini lebih efektif dilakukan dalam kelompok dengan anggota 3-5 siswa. Anggota kelompok diatur secara heterogen dan dalam kelompok siswa diminta membaca, membuat catatan kecil, 
menjelaskan, mendengarkan, menanggapi dan melengkapinya dengan tulisan dalam suasana yang aktif dan menyenangkan (Suadnyana, 2016).Penerapan model pembelajaran TTW ini diharapkan dapat membantu guru dalam mengatasi berbagai permasalahan yang timbul saat melaksanakan pembelajaran Ilmu Pengetahuan Sosial (IPS) di kelas III Gugus IX Kecamatan Banjar.

Berdasarkan uraian di atas, maka perlu kiranya suatu upaya yang dilakukan untuk mengoptimalkan hasil belajar IPS melalui model pembelajaran Think Talk Write (TTW) berbantuan penilaian portofolio yang dapat meningkatkan hasil belajar IPS siswa. Oleh karena itu, maka dirumuskan judul penelitian "Pengaruh Model Pembelajaran Think Talk Write (TTW) Berbantuan Penilaian Portofolio terhadap Sikap Disiplin dan Hasil Belajar IPS Siswa Kelas III SD di Gugus IX Kecamatan Banjar Kabupaten Buleleng Tahun Pelajaran 2018/2019.

\section{Metode}

Penelitian ini menggunakan metode eksperimen. Sedangkan jenis penelitian ini adalah penelitian eksperimen semu (quasy exsperiment). Peneliti tidak mungkin mengubah kelas dalam menentukan subjek atau kelas untuk kedua pembelajaran yaitu pembelajaran dengan menerapkan model pembelajaran Think Talk Write (TTW) berbantuan penilaian portofolio dan pembelajaran konvensional. Rancangan penelitian yang digunakan adalah the posttest-only control-group desain. Populasi dalam penelitian ini adalah semua siswa kelas III SD Gugus IX Kecamatan Banjar yang menggunakan Kurikulum Tingkat Satuan Pendidikan yakni sebanyak 153 orang, dengan rincian anggota populasi dapat dilihat pada tabel 2 berikut.

Tabel 2. Data Jumlah Populasi Penelitian Siswa Kelas III SD Gugus IX Kecamatan Banjar Tahun Pelajaran $2018 / 2019$

\begin{tabular}{|c|c|c|}
\hline No. & Sekolah & Jumlah \\
\hline 1 & SD Negeri 1 Gobleg & 12 \\
\hline 2 & SD Negeri 2 Gobleg & 37 \\
\hline 3 & SD Negeri 3 Gobleg & 7 \\
\hline 4 & SD Negeri 4 Gobleg & 31 \\
\hline 5 & SD Negeri 5 Gobleg & 26 \\
\hline 6 & SD Negeri 6 Gobleg & 15 \\
\hline \multirow[t]{2}{*}{7} & SD Negeri 2 Pedawa & 25 \\
\hline & Total Populasi & 153 \\
\hline
\end{tabular}

Berdasarkan tabel 2, sampel ditentukan dengan menggunakan random sampling. Sebelum menetapkan sampel penelitian, dilakukan uji kesetaraan pada masing-masing kelas terlebih dahulu. Uji kesetaraan yang dilakukan menggunakan uji ANAVA A, jika hasil Fhitung kurang dari Nilai $\mathrm{F}_{\text {tabel }}$ maka kelas tersebut tidak setara. Sedangkan jika hasil $F_{\text {hitung }}$ lebih besar dari Nilai $\mathrm{F}_{\text {tabel }}$ maka kelas tersebut setara. Berdasarkan uji kesetaraan yang telah dilakukan pada 7 sekolah di SD Gugus IX Kecamatan Banjar menggunakan uji ANAVA $A$ didapatkan hasil Fhitung $=0,54$. Sedangkan dengan $\mathrm{db}_{\mathrm{A}}=7$, dan $\mathrm{db}_{\mathrm{dalam}}=153$ didapatkan harga $F_{\text {tabel }}$ sebesar 2,16 pada taraf signifikasi $5 \%$. Sehingga dapat disimpulkan bahwa $F_{\text {hitung }}<$ $\mathrm{F}_{\text {tabel }}(0,54<2,16)$ dengan taraf signifikansi $5 \%$ ini berarti $\mathrm{H}_{0}$ diterima, dengan demikian tidak terdapat perbedaan yang signifikan hasil belajar IPS siswa kelas III SD Gugus IX Kecamatan Banjar. Hal tersebut berarti, setiap anggota populasi yakni seluruh siswa kelas III SD Gugus IX Kecamatan Banjar adalah setara atau homogen dan dapat dijadikan sebagai sampel penelitian.

Berdasarkan uji kesetaraan yang telah dilakukan didapatkan hasil bahwa seluruh kelas III yang ada di SD Gugus IX Kecamatan Banjar memiliki kemampuan yang setara. Dalam menunjuk kelas eksperimen dan kelas kontrol, peneliti melakukan sistem undian. Berdasarkan sistem undian yang telah dilakukan, maka dapat disimpulkan bahwa SD N 4 Gobleg sebagai kelompok eksperimen dan SD 2 Gobleg sebagai kelompok kontrol.

Data pada penelitian ini dikumpulkan dengan beberapa metode pengumpulan data yang disesuaikan dengan tuntutan data dari masing-masing rumusan permasalahan. Oleh karena itu data yang diperoleh haruslah valid dan reliabel. Berkaitan dengan permasalahan yang dikaji pada penelitian ini maka ada dua jenis data yang diperlukan, yakni sikap disiplin siswa pada saat pembelajaran dan hasili belajar IPS siswa. Untuk mengumpulkan data mengenai sikap disiplin siswa dalam pembelajaran IPS dikumpulkan menggunakan non tes berupa lembar observasi dan pemberian angket di akhir pelaksanaan penelitian. Lembar observasi dan angket yang dibuat berdasarkan syarat-syarat pembuatan instrumen dengan modifikasi dari skala Likert. Sedangkan data mengenai hasil belajar IPS dikumpulkan dengan memberikan tes pilihan ganda dengan empat pilihan. 
Pada penelitian ini digunakan instrumen sesuai dengan jenis dan sifat data yang dicari. Dalam penyusunan instrument, terlebih dahulu dibuat kisi-kisi. Kisi-kisi hasil belajar dibuat dengan berpedoman pada landasan kurikulum yang ada yakni kurikulum KTSP 2006 menyangkut standar kompetensi, kompetensi dasar, aspek materi dan indikatornya. Sedangkan kisi-kisi instrumen sikap disiplin dibuat berdasarkan gabungan teori dari beberapa ahli yakni Anas Sudjono dan Ngalim Purwanto yang menyatakan bahwa sikap disiplin adalah bagian dari tingkah laku manusia sebagai gejala atau gambaran kepribadian yang memancar kelur.

Sebelum instrumen digunakan, terlebih dahulu dilakukan oleh dua orang pakar guna mendapatkan kualitas tes yang baik. Setelah selesai dilakukan expert judgment maka instrumen diujicobakan ke lapangan untuk mengetahui validitas dan reliabilitas instrument tersebut. Dalam uji validitas butir angket sikap disiplin menggunakan rumus product momment dan uji reliabilitas angket sikap disiplin digunakan rumus alpha cronbach.

Berdasarkan hasil uji pakar, angket sikap disiplin dan tes hasil belajar IPS seluruh itemnya relevan dan validitasnya berada pada kategori sangat tinggi. Sedangkan berdasarkan uji coba lapangan kepada 82 orang siswa, validitas keempat indikator angket sikap disiplin dengan 25 butir pernyataan, 20 butir pernyataan valid dan 5 butir pernyataan gugur, dan reliabilitasnya sebesar 1,027 sehingga tergolong pada kategori sangat tinggi.

Untuk tes hasil belajar IPS butir soal yang diujicobakan sebanyak 40 butir soal, kepada 82 orang. Berdasarkan uji coba tersebut sebanyak 30 butir soal valid dan 10 butir soal gugur. Kemudian untuk angka reliabilitasnya sebesar 0,77 sehingga berada pada kategori tinggi. Dalam uji daya beda diperoleh 9 butir soal memiliki kriteria daya beda tes baik, 11 butir soal yang memiliki kriteria daya beda tes cukup, dan 10 butir soal yang memiliki kriteria daya beda tes cukup baik. Sehingga berdasarkan uji daya beda 30 butir soal dinyatakan valid. Sedangkan uji taraf kesukaran tes diketahui 18 soal dengan kategori mudah, 9 soal dengan kategoi sedang, dan 3 soal dengan kategori sukar. Berdasarkan uji pakar dan uji lapangan, maka butir soal tes hasil belajar yang valid adalah sebanyak 30 soal.

Hasil penelitian dalam penelitian ini dianalisis secara bertahap, yaitu: deskripsi data, uji prasyarat, dan uji hipotesis. Uji prasyarat yang dilakukan adalah uji normalitas sebaran data, uji homogenitas varians, dan uji korelasi antar variabel terikat. Uji normalitas dilakukan untuk meyakinkan bahwa sampel berasal dari populasi yang berdistribusi normal, sehingga uji hipotesis dapat dilakukan. Uji normalitas data dilakukan pada empat kelompok data yaitu: 1) data sikap disiplin kelompok eksperimen, 2) data sikap disiplin kelompok kontrol, 3) data hasil belajar kelompok eksperimen, dan 4) data hasil belajar kelompok kontrol.

Uji homogenitas dimaksudkan untuk memperlihatkan bahwa dua atau lebih kelompok data sampel berasal dari populasi yang memiliki variansi yang sama, sedangkan uji korelasi antar variabel terikat dilakukan untuk mengetahui apakah korelasi antar variabel terikat tersebut tinggi atau rendah. Karena, jika korelasi antar variabel terikat tinggi maka variabel terikat tidak dapat dipisahkan, sedangkan jika korelasi antar variabel terikat rendah atau tidak ada korelasi maka variabel terikat dalam penelitian ini dapat dipisahkan.

Hipotesis dalam penelitian ini adalah a) terdapat perbedaan sikap disiplin antara siswa yang mengikuti model pembelajaran Think Talk Write berbantuan penilaian portofolio dengan siswa yang mengikuti pembelajaran konvensional pada siswa kelas III SD Gugus IX Kecamatan Banjar Tahun Pelajaran 2018/2019, b) terdapat perbedaan hasil belajar IPS antara siswa yang mengikuti model pembelajaran Think Talk Write berbantuan penilaian portofolio dengan siswa yang mengikuti pembelajaran konvensional pada siswa kelas III SD Gugus IX Kecamatan Banjar Tahun Pelajaran 2018/2019, c) secara simultan, terdapat perbedaan sikap disiplin antara siswa yang mengikuti model pembelajaran Think Talk Write berbantuan penilaian portofolio dengan siswa yang mengikuti pembelajaran konvensional pada siswa kelas III SD gugus IX Kecamatan Banjar Tahun Pelajaran 2018/2019.

Dalam pengujian hipotesis 1 dan 2 pada penelitian ini menggunakan uji ANAVA $A$, sedangkan pengujian hipotesis 3 dilakukan dengan uji MANOVA. Selain menggunakan perhitungan manual, data juga dianalisis menggunakan bantuan SPSS-17.00 for windows pada signifikansi 5\%.

\section{Hasil dan Pembahasan}

Objek dalam penelitian ini adalah sikap disiplin dan hasil belajar IPS siswa sebagai hasil perlakuan antara model pembelajaran Think Talk Write berbantuan penilaian portofolio dan pembelajaran konvensional. Ada tiga hal yang dibandingkan dalam penelitian ini, yaitu: 1) model pembelajaran Think Talk Write berbantuan penilaian portofolio dengan model pembelajaran konvensional dalam peningkatan sikap disiplin siswa; 2) model pembelajaran Think Talk Write berbantuan penilaian portofolio dengan 
pembelajaran konvensional dalam peningkatan hasil belajar siswa; 3) model pembelajaran Think Talk Write berbantuan penilaian portofolio dengan pembelajaran konvensional dalam peningkatan sikap disiplin dan hasil belajar siswa secara simultan

Tabel 3. Rangkuman hasil analisis statistik deskriptif

\begin{tabular}{lccccc}
\hline \multicolumn{1}{c}{ Statistik } & Variabel & A1 & & \multicolumn{2}{c}{ A2 } \\
& Y1 & Y2 & Y1 & Y2 \\
\hline N & 31 & 37 & 31 & 37 \\
Mean & 70,23 & 65 & 68,67 & 67,41 \\
Median & 78 & 60 & 66,7 & 60,9 \\
Modus & 77,7 & 65,5 & 69 & 78 \\
Standar Deviasi & 7,20 & 4,38 & 9,23 & 9,87 \\
Varians & 51,90 & 19,17 & 85,23 & 97,36 \\
Range & 25 & 16 & 41 & 41 \\
Minimum & 60 & 60 & 50 & 50 \\
Maksimum & 80 & 75 & 90 & 90 \\
\hline
\end{tabular}

Berdasarkan tabel 3 analis deskriptif data, tampak bahwa sikap disiplin dan hasil belajar IPS siswa yang dibelajarkan dengan model pembelajaran Think Talk Write berbantuan penilaian portofolio lebih baik daripada model pembelajaran konvensional. Hal ini ditunjukkan oleh rata-rata nilai sikap disiplin siswa yang mengikuti pembelajaran dengan menerapkan model pembelajaran Think Talk Write berbantuan penilaian portofolio adalah 70,23 , sedangkan rata-rata nilai sikap disiplin siswa yang mengikuti pembelajaran yang menerapkan model pembelajaran konvensional adalah sebesar 65 . Nilai rata-rata hasil belajar IPS siswa yang mengikuti pembelajaran dengan menerapkan model pembelajaran Think Talk Write berbantuan penilaian portofolio adalah 68,67, sedangkan rata-rata nilai hasil belajar IPS siswa yang mengikuti pembelajaran yang menerapkan model pembelajaran konvensional adalah 67,41. Oleh karena itu, maka dapat disimpulkan bahwa sikap disiplin dan hasil belajar IPS siswa yang mengikuti model pembelajaran Think Talk Write berbantuan penilaian portofolio lebih baik daripada sikap disiplin dan hasil belajar IPS siswa yang mengikuti model pembelajaran konvensional. Setelah didapatkan hasil analisis deskriptif data, maka dilanjutkan dengan uji prasyarat. Uji prasyarat yang dilakukan adalah uji normalitas sebaran data, uji homogenitas varians, dan uji antar variabel terikat.

Untuk menguji normalitas sebaran data, digunakan SPSS-17.00 for windows. Berdasarkan hasil analisis menggunakan SPSS-17.00 for windows dengan melihat uji statistik Kolmonogov-smirnov pada taraf signifikansi 0,05, maka didapatkan hasil seperti Tabel 4.

Tabel 4. Uji Normalitas sebaran data

\begin{tabular}{|c|c|c|c|c|}
\hline \multirow{2}{*}{ Variabel } & \multicolumn{3}{|c|}{ Kolmogorov-Smirnov } & \multirow{2}{*}{ Keterangan } \\
\hline & Statistic & $\mathrm{Df}$ & Sig & \\
\hline $\begin{array}{l}\text { Sikap Disiplin Siswa yang belajar dengan } \\
\text { model pembelajaran Think Talk Write } \\
\text { berbantuan penilaian portofolio }\end{array}$ & 0,151 & 31 & 0,063 & $\begin{array}{l}\text { Distribusi } \\
\text { Normal }\end{array}$ \\
\hline $\begin{array}{l}\text { Hasil Belajar Siswa yang belajar dengan } \\
\text { model pembelajaran Think Talk Write } \\
\text { berbantuan penilaian portofolio }\end{array}$ & 0.120 & 31 & 0.283 & $\begin{array}{l}\text { Distribusi } \\
\text { Normal }\end{array}$ \\
\hline $\begin{array}{l}\text { Sikap Disiplin Siswa yang belajar dengan } \\
\text { pembelajaran konvensional }\end{array}$ & 0.139 & 37 & 0.117 & $\begin{array}{c}\text { Distribusi } \\
\text { Normal }\end{array}$ \\
\hline $\begin{array}{l}\text { Hasil Belajar Siswa yang belajar dengan } \\
\text { pembelajaran konvensional }\end{array}$ & 0.138 & 37 & 0.283 & $\begin{array}{c}\text { Distribusi } \\
\text { Normal }\end{array}$ \\
\hline
\end{tabular}

Berdasarkan Tabel 4, terlihat bahwa semua variabel angka statistik kolmogorov- Smirnov lebih besar dari 0,05. Hal itu menunjukkan bahwa semua sebaran data berdistribusi normal. Setelah diketahui bahwa seluruh sebaran data berdistribusi normal, maka dilanjutkan dengan uji homogenitas varians. Untuk menguji homogenitas varians, digunakan SPSS-17.00 for windows. Berdasarkan hasil analisis menggunakan SPSS-17.00 for windows maka didapatkan hasil seperti Tabel 5 
Tabel 5. Hasil Analisis Uji Levene's Test

\begin{tabular}{rrrrl}
\hline & F & df1 & df2 & Sig. \\
\hline Sikap Disiplin & 0.776 & 1 & 66 & 0.483 \\
\hline Hasil belajar IPS & 0.122 & 1 & 66 & 0.728 \\
\hline
\end{tabular}

Berdasarkan Tabel 03 dan Tabel 04, tampak bahwa angka signifikansi yang dihasilkan baik secara bersama-sama maupun secara sendiri-sendiri lebih besar dari 0,05. Dengan demikian berarti matrik varian-kovarians terhadap variabel prestasi belajar dan keaktifan belajar siswa adalah homogen. Setelah uji normalitas sebaran data dan uji homogenitas varians dilakukan, maka dilanjutkan dengan menguji korelasi antar variabel terikat. Uji korelasi antar variabel terikat dilakukan menggunakan korelasi product moment pada taraf signifikansi 5\%. Pengujian ini dilakukan untuk menentukan jenis statistik yang digunakan untuk uji hipotesis. Apabila kedua data tidak berkorelasi maka uji hipotesis dilanjutkan dengan Manova, namun bila kedua data berkorelasi maka uji hipotesis dilakukan dengan jenis statistik yang lain. Hasil uji korelasi dengan product moment dapat dilihat pada tabel 7.

Tabel 6. Hasil Uji Product Moment

\begin{tabular}{|c|c|c|c|}
\hline Kelompok sampel & $r_{x y}$ & $\mathrm{r}_{\text {tabel }}$ & Kesimpulan \\
\hline $\begin{array}{l}\text { Sikap Disiplin dan hasil belajar siswa yang belajar } \\
\text { dengan model pembelajaran Think Talk Write } \\
\text { berbantuan penilaian portofolio }\end{array}$ & 0,15 & 0,355 & $\begin{array}{c}\text { Tidak } \\
\text { berkorelasi }\end{array}$ \\
\hline $\begin{array}{l}\text { Sikap disiplin dan hasil belajar siswa yang belajar } \\
\text { dengan pembelajaran konvensional }\end{array}$ & 0,14 & 0,325 & $\begin{array}{l}\text { Tidak } \\
\text { berkorelasi }\end{array}$ \\
\hline
\end{tabular}

Berdasarkan Tabel 6 di atas, maka data sikap disiplin dan hasil belajar IPS siswa yang belajar dengan model pembelajaran Think Talk Write berbantuan penilaian portofolio mendapatkan harga $\mathrm{r}_{\mathrm{xy}}=$ 0,15 , dengan harga $\mathrm{r}_{\text {tabel }}=0,355$ berarti nilai $\mathrm{r}_{\text {hitung }}<\mathrm{r}_{\text {tabel }}$ dan data siswa yang belajar dengan pembelajaran konvensional mendapatkan harga $r_{x y}=0,14$, nilai $r_{\text {hitung }}<r_{\text {tabel }}(0,325)$ pada taraf signifikansi $5 \%$, maka dapat disimpulkan bahwa data sikap disiplin dan hasil belajar IPS siswa yang belajar dengan model pembelajaran Think Talk Write berbantuan penilaian portofolio maupun siswa yang belajar dengan model pembelajaran konvensional tidak berkorelasi sehingga uji hipotesis dapat dilakukan dengan Manova.

Hasil uji hipotesis dalam penelitian ini membuktikan bahwa: pertama, sikap disiplin siswa yang dibelajarkan dengan model pembelajaran Think Talk Write berbantuan penilaian portofolio dan model pembelajaran konvensional menghasilkan harga $\mathrm{F}$ sebesar 13,48 $>\mathrm{F}_{\text {tabel }}(3,99)$ pada taraf signifikansi 5\%. Hal ini berarti, hipotesis nol $\left(\mathrm{H}_{\mathrm{o}}\right)$ ditolak dan hipotesis alternatif $\left(\mathrm{H}_{\mathrm{a}}\right)$ yang menyatakan "terdapat perbedaan keaktifan belajar antara siswa yang mengikuti model pembelajaran Think Talk Write berbantuan penilaian portofolio dengan siswa yang mengikuti pembelajaran konvensional", diterima.

Kedua, hasil belajar siswa yang dibelajarkan dengan model pembelajaran Think Talk Write berbantuan penilaian portofolio dan model pembelajaran konvensional menghasilkan harga $\mathrm{F}$ sebesar $82,78>\mathrm{F}_{\text {tabel }}(3,99)$ pada taraf signifikansi $5 \%$. Hal ini berarti, hipotesis nol $\left(\mathrm{H}_{0}\right)$ ditolak dan hipotesis alternatif $\left(\mathrm{H}_{\mathrm{a}}\right)$ yang menyatakan "terdapat perbedaan sikap disiplin siswa kelas III SD Gugus IX Kecamatan Banjar antara kelompok siswa yang dibelajarkan dengan model pembelajaran Think Talk Write berbantuan penilaian portofolio dengan kelompok siswa yang dibelajarkan dengan pembelajaran konvensional", diterima.

Ketiga, hasil analis menunjukkan bahwa harga F sebesar 6,743 dan nilai sig lebih kecil dari 0,05. Hal ini berarti hipotesis nol $\left(\mathrm{H}_{0}\right)$ ditolak dan hipotesis alternatif $\left(\mathrm{H}_{\mathrm{a}}\right)$ yang menyatakan "Secara simultan, terdapat perbedaan sikap disiplin dan hasil belajar IPS siswa kelas III SD Gugus IX Kecamatan Banjar antara siswa yang mengikuti model pembelajaran Think Talk Write berbantuan penilaian portofolio dengan siswa yang mengikuti pembelajaran konvensional", diterima.

Hasil uji hipotesis pertama menunjukkan bahwa sikap disiplin siswa yang dibelajarkan dengan model pembelajaran Think Talk Write berbantuan penilaian portofolio lebih tinggi dari sikap disiplin siswa yang dibelajarkan dengan menggunakan pembelajaran konvensional. Siswa yang mengikuti model Think Talk Write berbantuan penilaian portofolio memperoleh hasil nilai rata-rata yaitu 70,23 lebih tinggi dibandingkan dengan siswa yang mengikuti pembelajaran konvensional yang hanya memperoleh nilai rata-rata 65. Hal ini menunjukkan sikap disiplin kelompok siswa yang dibelajarkan dengan model TTW berbantuan penilaian portofolio lebih tinggi dibandingkan dengan kelompok siswa yang mengikuti pembelajaran konvensional. 
Sejalan dengan pendapat yang dikemukakan oleh Astianawan (2016) yang menyatakan, model pembelajaran TTW adalah suatu model pembelajaran untuk melatih keterampilan peserta didik menulis dan menekankan perlunya peserta didik mengomunikasikan hasil pemikirannya. Hasil penelitian ini sejalan dengan temuan penelitian Ariasa (2015) mengenai Pengaruh Model Pembelajaran TTW Berbantuan Media Gambar Terhadap Hasil Belajar Bahasa Indonesia Siswa Kelas IV di Gugus VIII Kecamatan Buleleng. terdapat pengaruh signifikasi model pembelajaran TTW berbantuan media gambar terhadap hasil belajar siswa kelas IV SD di Gugus VIII Kecamatan Buleleng. Hasil uji hipotesis kedua menunjukkan bahwa terdapat perbedaan hasil belajar IPS siswa yang mengikuti pembelajaran model TTW berbantuan penilaian portofolio antara siswa yang mengikuti pembelajaran konvensial. Siswa yang mengikuti model TTW berbantuan penilaian portofolio memperoleh hasil belajar rata-rata yaitu 68,67 lebih tinggi dibandingkan dengan siswa yang mengikuti pembelajaran konvensional yang hanya memperoleh nilai rata-rata 67,41. Hal ini menunjukan hasil belajar kelompok siswa yang dibelajarkan dengan model TTW berbantuan penilaian portofolio lebih tinggi dibandingkan dengan hasil belajar kelompok siswa yang mengikuti pembelajaran konvensional. Hal tersebut dikarenakan siswa yang mengikuti model pembelajaran TTW merasa pembelajaran lebih menyenangkan.

Temuan ini didukung oleh penelitian Arya, (2015) yang berjudul "Pengaruh Pendekatan Saintifik Berbasis Asesmen Portofolio Terhadap Hasil Belajar Pengetahuan Bahasa Indonesia dan Sikap Sosial Siswa Kelas IV pada Tema Cita-Citaku di SD 36 Gugus Moch. Hatta Denpasar. Siswa yang belajar dengan model pembelajaran TTW berbantuan penilaian portofolio menunjukkan hasil belajar IPS yang lebih baik dibandingkan dengan siswa yang belajar dengan model pembelajaran konvensional.

Hasil uji hipotesis ketiga menunjukkan terdapat perbedaan yang simultan antara siswa yang mengikuti pembelajaran model TTW berbantuan penilaian portofolio dengan siswa yang mengikuti pembelajaran konvensional. Siswa yang mengikuti model pembelajaran TTW berbantuan portofolio memperoleh hasil analisis, nilai F Pillai's Trace, Wilks' Lambda, Hotelling's Trace, Roy's Largest Root adalah 6,743 seluruhnya memiliki signifikansi 0,000 dan lebih kecil dari 0,05 $(0,000<0,05)$, hal ini menunjukkan terdapat perbedaan secara simultan sikap disiplin dan hasil belajar IPS antara siswa yang mengikuti model pembelajaran TTW dengan siswa yang mengikuti mdel pembelajaran Konvensional pada siswa kelas III SD Gugus IX Kecamatan Banjar.

Hasil penelitian ini sejalan dengan temuan penelitian Warsini, (2015) mengenai Pengaruh Pendekatan Saintifik Berbasis Assesmen Portofolio Terhadap Hasil Belajar Pengetahuan Bahasa Indonesia (Keterampilan Membaca) dan Sikap Spiritual Siswa Kelas IV SD pada Tema Cita-Citaku. terdapat perbedaan sikap disiplin dan hasil belajar IPS siswa yang mengikuti pembelajaran model pembelajaran TTW lebih tinggi dari pada siswa yang mengikuti pembelajaran dengan model pembelajaran konvensional.

\section{Simpulan dan Saran}

Berdasarkan hasil pengujian hipotesis dan pembahasan, maka simpulan dari penelitian ini adalah sebagai berikut:1) Terdapat perbedaan sikap disiplin antara siswa yang dibelajarakan dengan model pembelajaran TTW dan siswa yang dibelajarkan dengan pembelajaran konvensional pada siswa kelas III SD Gugus IX Kecamatan Banjar. Rata-rata nilai sikap disiplin yang dibelajarkan dengan model pembelajaran TTW sebesar 70,23 dan tata-rata sikap disiplin yang dibelajarkan dengan pembelajaran konvensional sebesar 65. Dari hasil uji Anava satu jalur juga dapat diketahui bahwa diperoleh nilai sig. sebesar $0,065<0,05$ dan F hitung $=13,48$. Dengan demikian sikap disiplin siswa yang dibelajarkan dengan model pembelajaran TTW berbantuan penilaian portofolio lebih baik dibandingkan dengan yang dibelajarkan dengan pembelajaran konvensional; Terdapat perbedaan hasil belajar IPS antara siswa yang mengikuti model pembelajaran TTW dan siswa yang mengikuti model pembelajaran konvensional pada siswa kelas III SD Gugus IX Kecamatan Banjar. Rata-rata nilai hasil belajar yang dibelajarkan dengan model pembelajaran TTW sebesar 68,67 dan tata-rata hasil belajar IPS yang dibelajarkan dengan model pembelajaran konvensional sebesar 67,41. Dari hasil uji Anava satu jalur juga dapat diketahui bahwa diperoleh nilai sig. sebesar $0,000<0,05$ dan $F$ hitung $=82,78$. Dengan demikian hasil belajar IPS siswa yang dibelajarkan dengan model pembelajaran TTW berbantuan penilaian portofolio lebih baik dibandingkan dengan yang dibelajarkan dengan pembelajaran konvensional; Terdapat perbedaan simultan sikap disiplin dan hasil belajar IPS siswa kelas III SD Gugus IX Kecamatan Banjar. Sesuai hasil analisis nilai rata-rata sikap disiplin pada siswa yang mengikuti model pembelajaran TTW lebih tinggi dibandingkan siswa yang mengikuti pembelajaran konvensional. Begitu pula dengan nilai rata-rata hasil belajar IPS siswa yang mengikuti model pembelajaran TTW lebih tinggi dibandingkan nilai rata-rata siswa yang mengikuti pembelajaran konvensional. Hal ini berarti antara sikap disiplin dan hasil belajar 
mengalami peningkatan, atau adanya peningkatan rata-rata nilai sikap disiplin dan nilai hasil belajar IPS siswa secara simultan setelah mengikuti model pembelajaran TTW berbantuan penilaian portofolio.

Berdasarkan simpulan penelitian yang telah dipaparkan, maka saran yang dapat diberikan adalah. Pertama, hasil penelitian menunjukkan bahwa siswa yang belajar dengan model pembelajaran TTW berbantuan penilaian portofolio secara signifikan memiliki sikap disiplin siswa yang tinggi daripada siswa yang mengikuti pembelajaran konvensional. Untuk itu model ini hendaknya diperkenalkan dan dikembangkan kepada pendidik guna menciptakan suasana yang menyenangkan namun tetap fokus. Kedua, kepada guru disarankan agar menerapakan model pembelajaran TTW karena hasil penelitian membuktikan bahwa penggunaan model pembelajaran TTW mampu meningkatkan sikap disiplin dan hasil belajar siswa. Ketiga, Kepada kepala sekolah agar dapat menggunakan hasil penelitian ini sebagai bahan acuan pedoman untuk membimbing guru-guru dalam melaksanakan pembelajaran dengan menggunakan model pembelajaran untuk meningkatkan keaktifan belajar dan hasil belajar siswa. Keempat, Kepada peneliti lain agar hasil penelitian ini dapat digunakan sebagai acuan kepustakaan untuk melakukan penelitian dalam variabel yang sama ataupun pada variabel yang berbeda.

\section{Daftar Rujukan}

Ariasa, J. (2015). Pengaruh Model TTW Berbantuan Media Gambar terhadap Hasil Belajar Bahasa Indonesia Siswa SD Kelas IV Universitas Pendidikan Ganesha.

Arya, I. W., Putra, I. K. A., Kristiantari, M. G. R. (2015). Pengaruh Pendekatan Saintifik Berbasis Asesmen Portofolio Terhadap Hasil Belajar Pengetahuan Bahas Indonesia dan Sikap Sosial Siswa Kelas IV pada Tema Cita-Citaku di SD Gugus Moch Hatta Denpasar Retrieved from. Retrieved from https://ejournal.undiksha.ac.id/index.php/JJPGSD/article/view/5072/3828

Astianawan, I. P. (2016). Penerapan Pendekatan Saintifik Berbasis Penilaian Portofolio Dapat Meningkatkan Kemampuan Pemecahan Masalah Dan Penguasaan Kompetensi Pengetahuan $\begin{array}{llllll}\text { Matematika } & \text { Siswa } & \text { Kelas } & \text { III, } & \text { Retrieved }\end{array}$ https://ejournal.undiksha.ac.id/index.php/JJPGSD/article/view/7088

Ayu, N. (2017). Pendidikan Karakter Sebagai Pilar Pembentukan Karakter Bangsa. Jurnal Fakultas Ilmu Sosial Universitas Negeri Medan Tahun 2017, 1(1), 348-352.

Hidayat, R. (2017). Keefektifan Model Pembelajaran Think Talk Write Berbantuan Media Puzzle Terhadap Hasil Belajar Siswa Kelas V Mata Pelajaran IPS SD Negeri Kutorisari 02 Batang, (1), 179-185. Retrieved from https://ejournal.undiksha.ac.id/index.php/JISD/article/view/11839/7703.

Juniardi, A. (2017). Pengaruh Model Pembelajaran TTW Berbantuan Media Video terhadap Hasil Belajar IPA Kelas V SD, 1-10. https://ejournal.undiksha.ac.id/index.php/JJPGSD/article/view/10788

Nurul, dkk. (2016). Pengaruh Sikap Kedisiplinan dan Kejujuran Peserta Didik Terhadap Hasil Belajar Biologi. Retrieved from http://journal.uinalauddin.ac.id/index.php/biotek/article/view/1892/1832

Rahmawati, dkk. (2016). Pengaruh Pendekatan Saintifik Berbasis Portofolio Terhadap Penguasaan Kompetensi Pengetahuan IPS Ditinjau Dari Kepercayaan Diri. E-Journal PGSD Universitas Pendidikan Ganesha, 4(1), 2.

Rusman. (2015). Pembelajaran Tematik Terpadu Teori Praktik dan Penilaian. Jakarta: Rajawali Pres.

Suadnyana, K. D. U. A. (2016). Penerapan Pendekatan Saintifik Berbasis Portofolio dapat Meningkatkan Penguasaan Kompetensi Pengetahuan IPS dan Motivasi Berprestasi, 1, 1-10.

Surapranata, S. \& M. H. (2014). Penilaian Portofolio Implementasi Kurikulum 2014. Bandung: PT Remaja Rosdakarya.

Susanto, A. (2013). Teori Belajar \& Pembelajaran di SD. Jakarta: PT Kharisma Putra Utama.

Trianto. (2010). Model Pembelajaran Terpadu Konsep, Strategi, dan Implementasinya dalam KTSP. Jakarta: Kencana Prenada Media Group.

Warsini, K. D., Putra, I. K. A., \& Kristiantari, M. G. R. (2015). Pengaruh Pendekatan Saintifik Berbasis Assesmen Portofolio Terhadap Hasil Belajar Pengetahuan Bahasa Indonesia (Keterampilan Membaca) dan Sikap Spiritual Siswa Kelas IV SD pada Tema Cita-Citaku. Retrieved from https://ejournal.undiksha.ac.id/index.php/JJPGSD/article/view/ 